\title{
DIGITAL ECONOMY - A BIBLIOMETRIC ADDITION TO UNDERSTANDING AN "UNDEFINED" DOMAIN OF THE ECONOMY
}

\begin{abstract}
Purpose: The definition of the digital economy changes depending on the time period the definition comes from and the prevailing technology of that period, from the Internet to advanced robotics or artificial intelligence. The purpose of this paper is to identify the core terms, give a definition of the digital economy, identify the most influential journals, authors and documents that deal with the topic and provide an overview of the development of academic literature over the years.
\end{abstract}

Methodology: 293 documents related to the term "digital economy" were retrieved from the Scopus database. By using citation, co-citation, bibliographic coupling analysis and co-occurrence of the keywords, this paper identifies a list of the most influential journals, authors and documents in the field of digital economy. The analysis was conducted by using the VOSviewer tool. An in-depth analysis of the documents was used to prepare an overview of the definitions of the digital economy.

Results: The research proves inconsistency of the definition and context of the digital economy as well as a significant impact of a small number of authors and journals in the area under study. Keyword analysis shows that the term digital economy is related not to macroeconomic terms but to more specific industrial terms.

Conclusion: Guidelines are provided for future scientific research to fill the gaps in the definition and scope of the digital economy.

Keywords: Digital economy, bibliographic analysis 


\section{Introduction}

The digital age is transforming every aspect of business. We communicate with images, produce by advanced robotics and 3D printers, transport by drones, pay by means of mobile payment applications, etc. The speed of information flow and its availability through the application of, among other things, the Internet of Things and cloud computing, enable companies to access new ideas. In the fast-paced world of innovations, digital technologies create many benefits that affect economic growth creating the digital economy. According to Chen (2020), the digital economy has "substantially reduced market friction but also posed new challenges for the efficient functioning of markets".

There are a large number of definitions of the digital economy that are not harmonized in practice, the scope and method of measurement. Digital Croatia (2014) defines the digital economy as a "newer form of economy based on digital technologies and as such represents one of the most attractive trends and opportunities for growth". According to Spremić (2017), "the concept of digital economy serves as an umbrella term for new business models, products and services based on digital technologies as the basic business infrastructure". Chen (2020) defines the digital economy as all the economic activities based on information and communication technologies, but Kupenova et al. (2020) narrow it down to "conducting business through markets based on the Internet and the WWW". A broader definition is given by $\mathrm{Mi}$ ethlich et al. (2020), who explained the digital economy as a set of social relations that "arise in connection with the production, sale and consumption of digital goods and services or with the use of digital infrastructure". By analyzing documents included in the research, we realized that in recent documents the term "digital economy" is often used to define the field in which the documents are published, although the term digital economy is generally not elaborated in the documents. According to Rustamof et al. (2021), "the lack of definition of the digital economy is the obstacle to discussing many issues", so this research has two goals: to systematize academic contributions and knowledge about the observed field of digital economy and by using bibliometric analysis to identify the most influential authors, journals and documents in the analyzed area. The initial hypotheses of the paper are:

1. Research of keywords related to the term "digital economy" will show a strong connection between the digital economy and macroeconomic concepts such as GDP, macroeconomics, economic development, economy growth, etc.

2. The field of the digital economy is not defined clearly and unambiguously.

\section{Literature overview}

Since the digital economy still has an insufficient share in GDP, Ajeti (2003) emphasizes that at the same time two different economies adapt and change according to the needs of society: "mass economy (the economy of the industrial age that still exists due to mass consumption of material goods, accumulation of wealth and economies of scale and mass exploitation of raw materials and energy)" and the so-called information economy that "uses much less energy, raw materials and labor, and achieves better effects due to knowledge".

Ajeti (2003) stresses that although certain countries have significantly advanced in the development of the digital society, in some countries, and even within these countries and/or societies, there is an "old" economy which a certain part of the population relies on and which must not be neglected but gradually developed in line with the availability of technology and education of the workforce. Nitescu (2016) also distinguishes between the traditional and digital economies and further explains that the digital economy differs from the traditional economy in a wide range of features. Although the opinion that most frequently appears in the literature (Huggins, 2008; Nguyen \& Pham, 2011) is that richer countries have already reached a mature stage of the digital economy, this is usually not the case in practice. Ojanpera et al. (2018) argue that countries basically have an economy affected by various variations of natural resources, material factors, and the level and application of knowledge, and that the degree of the digital economy 
does not depend solely on a country's wealth. The measurement framework, the accuracy of statistics and their availability in certain regions can give the wrong impression of the level of development of the digital economy (Bukht \& Heeks, 2017). Some research studies (Dewan \& Kraemar, 2000; Pohjola, 2002; Yousefi, 2011) even show a negative impact of digital technology on the economic development of the country. Digital technologies have a significant impact on all areas of the "old" economy and create a basis for future faster growth of the digital economy. Barmuta et al. (2020) researched the main difficulties for the organizational restructuring process in digital format and identified the main functional area of changes. Rrustemi et al. (2020) argued that development of crypto-currencies has brought new opportunities in "efficient, borderless and secure flows of capital". Novikov (2020) analyzed the use of data science and big data technology in reducing downtime to reduce costs.

Nesterenko et al. (2020) discussed the possibility of using cloud computing and a large database in agricultural production, Resznik et al. (2020) explored the ways to "improve the fight against money laundering in the digital economy", and the Shibata (2020) explored "gig work", autonomous nature of this kind of employment and the benefits that "gig workers" can provide when solving specific issues.

Some authors list the basic characteristics or concepts which the digital economy relies on (Tapscott, 1996; Nitescu, 2016; Spremić, 2017; Ergunova et al., 2019) based upon which it can be concluded that the digital economy is characterized by knowledge, globalization, digital business models, the speed of change, supporting infrastructure, integration of independently developed technologies and the use of digital platforms. In addition to the benefits, the digital economy also carries certain challenges. Risks associated with information technology are technical errors, obsolescence, disloyal partners, business process downtime and a negative impact on reputation, with inadequate investments stressed as one of the biggest risks.
Friedrich et al. (2011) researched Eurostat data and tried to define the extent to which digitization changes certain industries, and created the Industry Digitization Index, which consists of the following four factors: input, production, output and infrastructure. The authors concluded that sectors that are the leaders in the process of digitization have a unique opportunity to build a lasting market advantage. "Digital Darwinism" (Solis \& Szymanski, 2016) favors companies that invest in change. Although such transformations require large resources and time, those who treat this process as longterm will have the expected return on investment, as opposed to those who expect immediate results.

\section{Research methodology}

The research was conducted by using author keywords and abstracts in the Scopus database. Although a certain bias of the author in the use of author keywords is possible, it was considered that these are the terms that best describe the content of the document. The term "digital economy" was used as a search keyword (Negroponte, 1995; Šonje, 2001; Nitescu, 2016).

Additional emphasis was placed on Scopus categories (Economy, Business, Management, Operations Research and Management Science). It is considered that the contextualization of the term "digital economy" should refer as a broader term to the concepts of economy, state, industry, etc., so we wanted to exclude documents that deal with specific categories under the digital economy topics. We obtained data on 293 documents included in the analysis.

Figure 1 shows the methodology process. Data retrieved from the Scopus database was refined according to the following command:

(KEY ("digital economy") AND ABS ("digital economy")) AND (LIMIT-TO (DOCTYPE, "ar")) AND (LIMIT-TO (SUBJAREA, "BUSI") OR LIMIT-TO (SUBJAREA, "SOCI") OR LIMIT-TO (SUBJAREA, "ECON")) AND (LIMIT-TO (LANGUAGE, "English”)) AND (LIMIT-TO (SRCTYPE, “j”)) 
Figure 1 Research protocol review

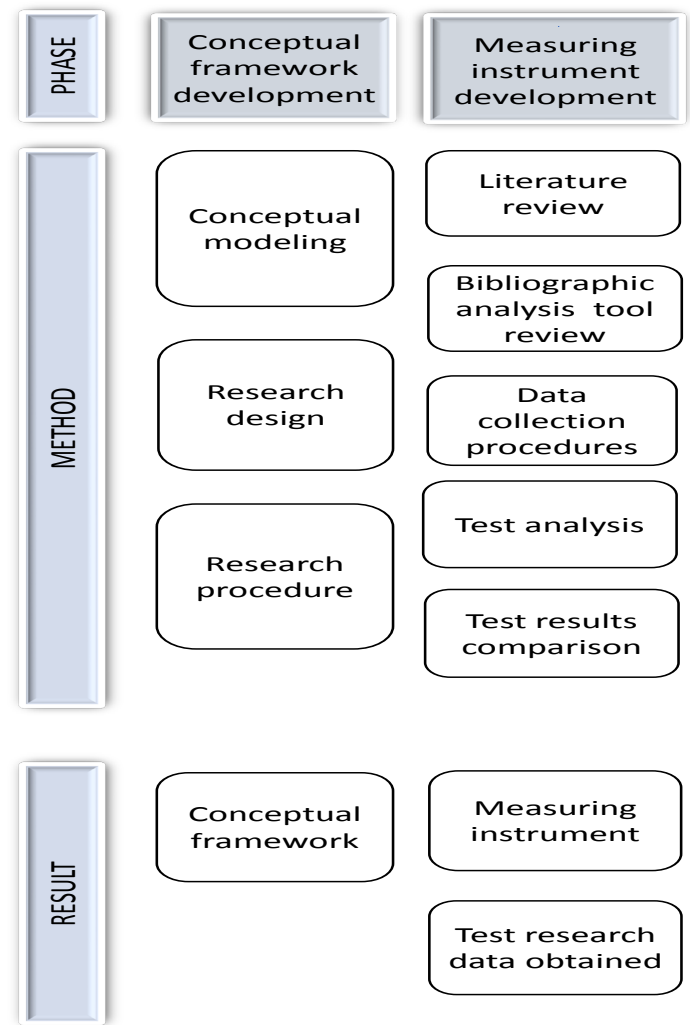

Source: Author, March 2021

In addition to the analysis of representation by years and countries, the VOSviewer program was used for the analysis of data obtained from the Scopus database (Van Eck \& Waltman, 2010).

Bibliometric analysis of journals, documents, authors, co-authorship of countries and co-occurrence of author keywords, index keywords and total keywords was performed. The aim was to determine the difference between author and index keywords as well as to identify the terms that are most frequently associated with the term digital economy. Additional data on these analyses can be found in Van Eck \& Waltman (2010).

The results presented in this paper were obtained by using citation, co-citation, bibliographic coupling and co-occurrence analysis. According to Surwase et al. (2011), co-citation analysis "involves tracking pair of papers that are cited together in the source articles". The mutual connection between
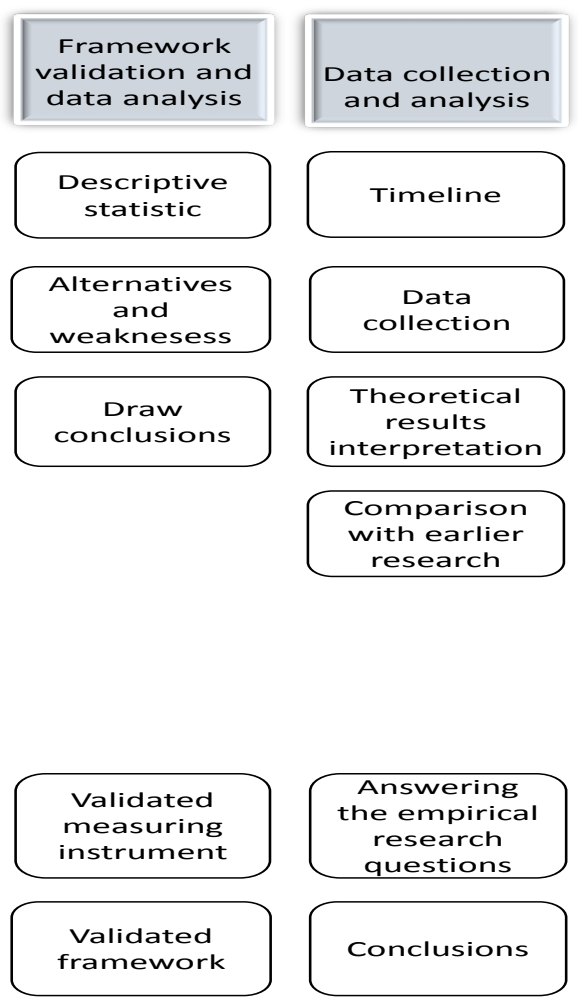

two documents is stronger when more documents cite both documents at the same time. According to Caputo et al. (2021), this connection provides an insight into the documents that are considered to be the foundations of the field under study.

Kessler (1963) first introduced the term bibliographic coupling. The analysis determines the relationship between two members that cited the same document (Ajibade \& Mutula, 2018).

According to Kessler (1963), bibliographic coupling occurs when two documents reference a common third document in their bibliographies. The bibliographic coupling strength increases with an increase in the number of references they have in common (Surwase et al., 2011). In the sum of strengths, this analysis represents the importance of the document network because the document with the highest strength is placed in the center of the network and it has the largest number of cita- 
tions related to other documents. The information shows the network of documents, authors or journals.

The co-authorship network defines organizations, authors or countries that establish cooperation, while according to Callon et al. (1983), co-occurrence is a form of keyword analysis that investigates their connection and the conceptual structure of the field.

The research is presented in overview tables. Overlay visualization enabled by the program is used in one case. Network visualization is determined by the circles representing the analyzed members connected by links of certain strength and in certain clusters. The size of the circle depends on the importance of the observed element and the distance referring to their connection - the closer they are, the stronger their connection. Overlay visualization shows the analyzed members in the same position, but the colors (from blue to yellow) of the member itself are determined depending on the period of time in which the document was published. The later the analyzed document is published, the closer its color is to yellow. An in-depth analysis of the content of specific documents was used to determine a different definition of the term digital transformation.

\section{Results}

\subsection{Source analysis}

Journals were analyzed from three perspectives, i.e. analysis of the most cited journals, analysis of the journals considered to be the basis of the analyzed field, and analysis of the journals with the largest network. For citation analysis, we selected journals that published at least two documents (Ferreira, 2018) and a set of 48 journals with 162 documents was obtained.

Fifty documents (30.8\%) were published in the ten most cited journals. Out of the total number of citations (979), 412 (42\%) and 600 (61.2\%) citations refer to the 5 and 10 most important journals, respectively. This clearly shows a strong impact of a small number of journals on the field under study. The average number of citations per journal is 20 .

The largest number of citations is related to MIS Quarterly (113), Entrepreneurship and Sustainability Issues (98), Management Science (82), Comput- er Law and Security Review (64) and the European Research Studies Journal (55).

Co-citation analysis shows a slightly different order. As a condition for analysis, 10 citations per journal were defined, so out of the total number of sources $(6,554)$, only 73 met the said condition. Only 5 journals have more than 30 citations and the first 10 according to citations $(0.15 \%$ of the total number of analyzed journals) account for $30.8 \%$ of all citations. The first 30 journals according to citations $(0.45 \%$ of the total number of analyzed journals) account for $60.37 \%$ of all citations. The journals that have the highest link strength and thus the most significant impact on the digital economy concept are MIS Quarterly (1187), Information Systems Research (584), Social Psychology Quarterly (564), Computers in Human Behavior (495), and the European Research Studies Journal (490).

Bibliographic coupling analysis was defined on a minimum of two documents per journal (Ferreira, 2018) and out of the 187 sources, 48 met this condition. This analysis shows that the following journals were at the core of the problem with the strongest network referring to the topic: the European Research Studies Journal, Technological Forecasting and Social Change, Technology in Society, Entrepreneurship and Sustainability Issues and Espacios.

It can be seen in the table below that the theoretical basis for the digital economy concept is most frequently found in journals covering the fields of business and management. Exceptionally important journals for researching the topic can be noticed in citation analysis, with $0.45 \%$ of journals having a $60.37 \%$ share in citations.

The only journal ranked in the top five journals by all criteria is the European Research Studies Journal, with 9 published documents (6.11 citations per document). At the same time, MIS Quarterly has 2 published documents and 56.5 citations per document. Therefore, when analyzing the field of the digital economy, special attention should be paid to the documents published in these journals. To understand the impact of an individual journal on the observed topic, it is extremely important to conduct all three analyzes.

Although some journals are not among the most cited journals, bibliographic coupling analysis can show that the importance of documents within such journals in the community dealing with the same topic is extremely high. 
Table 1 Comparison of citation, co-citation and bibliographic coupling of journals

\begin{tabular}{|c|c|c|c|c|c|c|c|}
\hline & \multicolumn{3}{|c|}{ Citation analysis } & \multicolumn{2}{|c|}{ Co-citation analysis } & \multicolumn{2}{|c|}{ Bibliographic coupling } \\
\hline & Source & $\begin{array}{l}\text { Docu- } \\
\text { ments }\end{array}$ & $\begin{array}{l}\text { Cita- } \\
\text { tions }\end{array}$ & Source & $\begin{array}{c}\text { Total links } \\
\text { strength }\end{array}$ & Source & $\begin{array}{l}\text { Total links } \\
\text { strength }\end{array}$ \\
\hline 1. & Mis Quarterly & 2 & 113 & Mis Quarterly & 1,187 & $\begin{array}{l}\text { European research } \\
\text { studies journal }\end{array}$ & 63 \\
\hline 2. & $\begin{array}{l}\text { Entrepreneurship and } \\
\text { Sustainability Issues }\end{array}$ & 6 & 98 & $\begin{array}{l}\text { Information sys- } \\
\text { tems research }\end{array}$ & 584 & $\begin{array}{l}\text { Technological fore- } \\
\text { casting and social } \\
\text { change }\end{array}$ & 59 \\
\hline 3. & Management science & 2 & 82 & $\begin{array}{l}\text { Social psychology } \\
\text { quarterly }\end{array}$ & 564 & $\begin{array}{l}\text { Technology in } \\
\text { society }\end{array}$ & 52 \\
\hline 4. & $\begin{array}{l}\text { Computer law and } \\
\text { security review }\end{array}$ & 5 & 64 & $\begin{array}{l}\text { Computers in hu- } \\
\text { man behavior }\end{array}$ & 495 & $\begin{array}{l}\text { Entrepreneurship } \\
\text { and sustainability } \\
\text { issues }\end{array}$ & 50 \\
\hline 5. & $\begin{array}{l}\text { European research } \\
\text { studies journal }\end{array}$ & 9 & 55 & $\begin{array}{l}\text { European research } \\
\text { studies journal }\end{array}$ & 490 & Espacios & 36 \\
\hline 6. & $\begin{array}{l}\text { International journal of } \\
\text { economics and busi- } \\
\text { ness administration }\end{array}$ & 3 & 52 & $\begin{array}{l}\text { Telecommunica- } \\
\text { tions policy }\end{array}$ & 480 & $\begin{array}{l}\text { Quality - access to } \\
\text { success }\end{array}$ & 12 \\
\hline 7. & Technovation & 2 & 36 & $\begin{array}{l}\text { International jour- } \\
\text { nal of information } \\
\text { management }\end{array}$ & 327 & $\begin{array}{l}\text { International jour- } \\
\text { nal of economics } \\
\text { and business ad- } \\
\text { ministration }\end{array}$ & 11 \\
\hline 8. & $\begin{array}{l}\text { Decision support } \\
\text { systems }\end{array}$ & 2 & 35 & $\begin{array}{l}\text { Management } \\
\text { science }\end{array}$ & 313 & $\begin{array}{l}\text { Journal of environ- } \\
\text { mental manage- } \\
\text { ment and tourism }\end{array}$ & 8 \\
\hline 9. & Espacios & 15 & 34 & $\begin{array}{l}\text { Government infor- } \\
\text { mation quarterly }\end{array}$ & 295 & Big data and society & 6 \\
\hline 10. & Technology in society & 4 & 31 & $\begin{array}{c}\text { Communications of } \\
\text { the acm }\end{array}$ & 283 & Economic analisys & 6 \\
\hline 11. & $\begin{array}{c}\text { Technological fore- } \\
\text { casting and social } \\
\text { change }\end{array}$ & 5 & 30 & $\begin{array}{l}\text { Harvard business } \\
\text { review }\end{array}$ & 274 & $\begin{array}{l}\text { International jour- } \\
\text { nal of supply chain } \\
\text { management }\end{array}$ & 6 \\
\hline 12. & $\begin{array}{l}\text { Telecommunications } \\
\text { policy }\end{array}$ & 2 & 30 & $\begin{array}{l}\text { Journal of entrepre- } \\
\text { neurship education }\end{array}$ & 273 & $\begin{array}{l}\text { Journal of entrepre- } \\
\text { neurship education }\end{array}$ & 6 \\
\hline 13. & $\begin{array}{l}\text { Foundations of man- } \\
\text { agement }\end{array}$ & 2 & 29 & Espacios & 248 & $\begin{array}{c}\text { Polish journal of } \\
\text { management studies }\end{array}$ & 6 \\
\hline 14. & $\begin{array}{l}\text { Computers and se- } \\
\text { curity }\end{array}$ & 2 & 28 & $\begin{array}{l}\text { Journal of business } \\
\text { research }\end{array}$ & 245 & Technovation & 5 \\
\hline 15. & $\begin{array}{l}\text { European journal of } \\
\text { social theory }\end{array}$ & 2 & 27 & $\begin{array}{l}\text { Management sci- } \\
\text { ence }\end{array}$ & 240 & $\begin{array}{l}\text { Business informat- } \\
\text { ics }\end{array}$ & 4 \\
\hline
\end{tabular}

Source: Author, March 2021

\subsection{Author analysis}

In citation analysis, the authors are presented individually, separately from the group of authors with whom they share the specific document included in the analysis. One author can publish several docu- ments together with various authors, so each of their documents is counted as one document by a specific author, and quotations from a specific document are added there. 
A criterion of at least one document and ten citations per author was selected for citation analysis, which amounted to 133 out of the 760 authors fulfilling the condition. These authors were cited 3,273 times, while only 59 authors were cited more than 20 times.

The most cited 10 authors $(7.51 \%)$ were mentioned in $24.2 \%$ of all citations, whereas 30 authors (i.e. $22.5 \%$ of all authors) in the analysis accounted for $47.14 \%$ of all citations.

Co-citation analysis defines authors who represent the foundations of the topic under study. A minimum threshold of 10 citations per author was defined (Ferreira, 2018). Using a limit of 20 citations, out of the total number of authors $(12,828)$ only 12 were selected, so the citation limit was adjusted to a smaller number (10) to conduct deeper analysis of the list. Forty-three authors, of whom Watanabe and Neittaanmaki are the most significant ones dealing with the analyzed topic (Table 2), defined such a limitation. The fact that by limiting the citations to 20 only 12 authors are obtained, shows that although the topic was accepted and developed by a large number of authors $(12,828)$, several of them represent the foundation to which most of the later documents are connected.

In order to conduct bibliographic coupling analysis, the limit is set to a minimum of one document and one citation per author. Based on this limit of 760 authors, 440 authors met the condition. According to the analysis, although Gordon and Loeb are the most cited authors, Neittaanmaki, Tou, and Watanabe are the authors who are at the center of the citation network and are most frequently embedded in conversation.

Table 2 Bibliographic analysis of authors

\begin{tabular}{|c|c|c|c|c|c|c|}
\hline & \multicolumn{2}{|l|}{ Citation } & \multicolumn{2}{|c|}{ Co-citation } & \multicolumn{2}{|c|}{ Bibliographic coupling } \\
\hline & Author & $\begin{array}{l}\text { No. of } \\
\text { citations }\end{array}$ & Author & $\begin{array}{l}\text { Total link } \\
\text { strength }\end{array}$ & Author & $\begin{array}{l}\text { Total link } \\
\text { strength }\end{array}$ \\
\hline 1. & Gordon, L.A. & 112 & Watanabe, C. & 1,748 & Neittaanmaki, P. & 942 \\
\hline 2. & Loeb, M.P. & 112 & Neittaanmaki, P. & 1,409 & Tou, Y. & 942 \\
\hline 3. & Sohail, T. & 112 & Naveed, K. & 1,217 & Watanabe, C. & 942 \\
\hline 4. & Geoffrion, A.M. & 91 & Tou, Y. & 748 & Kauffman, R. J. & 778 \\
\hline 5. & Krishnan, R. & 82 & Brynjolfsson, E. & 647 & Kim ,D.J. & 778 \\
\hline 6. & Polyakova, A. G. & 65 & Akhmetshin, E.M. & 387 & Lang, K.R. & 778 \\
\hline 7. & Grimes, $\mathrm{S}$. & 64 & Mcafee, A. & 343 & Li, R. & 778 \\
\hline 8. & Kierkegaard, P. & 57 & Tapscott, D. & 224 & Naldi, M. & 778 \\
\hline 9. & Loginov, M.P. & 50 & Polyakova, A. G. & 217 & Boychenko, O.V. & 510 \\
\hline 10. & Serebrennikova, A.I. & 50 & Goloshchapova, I.V. & 207 & Burkaltseva, D.D. & 510 \\
\hline 11. & Thalassinos, E.I. & 50 & Vornokova, O.Y. & 194 & Sivash, O.S. & 510 \\
\hline 12. & Akyuz, G.A. & 47 & Kamolov, S.G. & 166 & Zotova, S.A. & 510 \\
\hline 13. & Rehan, M. & 47 & Zhang, I. & 130 & Carter, $\mathrm{M}$. & 478 \\
\hline 14. & Neittaanmaki, P. & 41 & Heeks, R. & 112 & Grover, V. & 478 \\
\hline 15. & Tou, Y. & 41 & Venkatesh, V. & 110 & Petter, S. & 478 \\
\hline 16. & Watanabe, C. & 41 & Fountain, J.E. & 106 & Thacher, J.B. & 478 \\
\hline 17. & De Cock, C. & 38 & Davis, F.D. & 99 & Naveed, K. & 473 \\
\hline 18. & Pogodina, T.V. & 38 & Perez, C. & 95 & Bakhvalov, S.Y. & 414 \\
\hline 19. & Graham,G. & 36 & Mykland, P.A. & 90 & Kuznetsova, I.G. & 414 \\
\hline 20. & Li, F. & 36 & Fuchs, C. & 86 & Levichev, V.E. & 414 \\
\hline
\end{tabular}

Source: Author, March 2021 


\subsection{Document analysis}

Document analysis shows that the concept of the digital economy has been written about since 1998, and the peak was reached in 2019 and 2020. In the last 5 years, $82 \%$ of all documents included in this analysis have been published, which shows how interesting the topic has become.

\section{Figure 2 Documents per year}

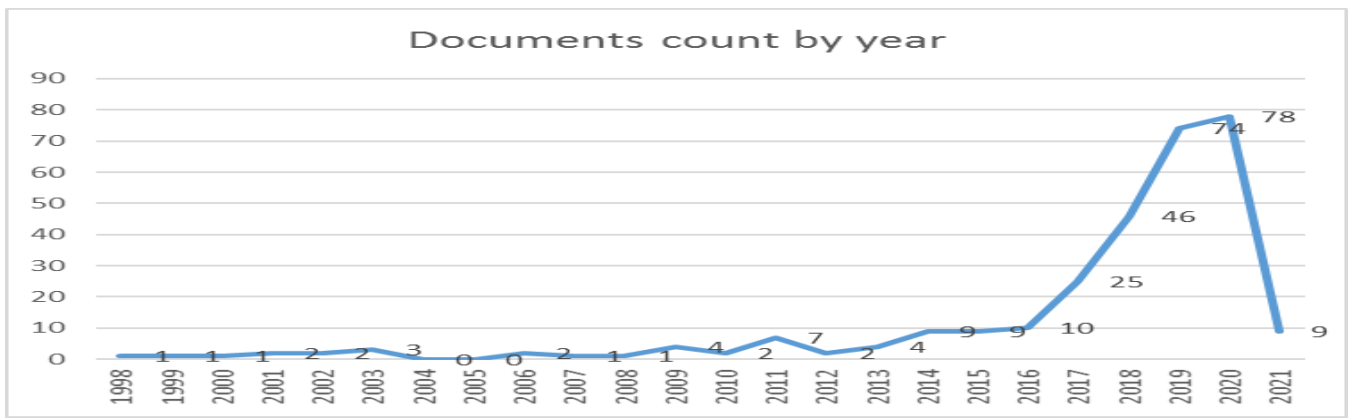

Source: Scopus, March 2021

The requirement for citation and bibliographic coupling analysis of documents is set at a minimum of five citations per author. Of 293 authors, 78 met the requirement in citation analysis. In bibliographic coupling analysis of 293 documents, 78 met the condition.

The most important documents according to citations are the following:

1. Gordon, L. A. et al. (2010). Market value of voluntary disclosures concerning information security.

2. Grimes, S. (2003). The digital economy challenge facing peripheral rural areas.

3. Kierkegaard, P. (2011). Electronic health record: Wiring Europe's healthcare.

4. Polyakova, A. G. et al. (2019). Design of a socio-economic processes monitoring system based on network analysis and big days.

5. Geoffrion, A. M. \& Krishnan, R. (2003). Ebusiness and management science: Mutual impacts (Part 1 of 2 ).

A document comparison table shows that the most cited documents are not the documents that are most networked within the topic. Documents with the highest link strength according to bibliographic coupling analysis are as follows:

1. Ali, M. A. et al. (2018). An empirical investigation of the relationship between e- government development and the digital economy: the case study of Asian countries.

2. Zhao, F. et al. (2015). E-government development and the digital economy: a reciprocal relationship.

3. Watanabe, C. et al. (2018). Measuring GDP in the digital economy: Increasing dependence on uncaptured GDP.

4. Watanabe, C. et al. (2018). A new paradox of the digital economy - Structural sources of the limitation of GDP statistic.

5. Geoffrion, A. M. \& Krishnan, R. (2003). Ebusiness and management science: Mutual impacts (Part 1 of 2).

The 20 most significant authors by citation and bibliographic coupling are presented in Table 3, where the difference can be noticed. Although the document by Ali et al. (2018) is not the most cited one, it is the most networked document in the discussion. The differences in the documents confirm the importance of comparative bibliometric analysis when it comes to establishing an understanding of the impact on the field under study.

Furthermore, the publication year of the document has an impact on the number of citations, so it is extremely important to either normalize citations that balance the impact of the publication year of the document or look at bibliographic coupling analysis to search for more recent, interesting documents. 
Table 3 Comparison of citation and bibliographic coupling of documents

\begin{tabular}{|c|c|c|c|c|}
\hline & \multicolumn{2}{|c|}{ Citation } & \multicolumn{2}{|c|}{ Bibliographic coupling } \\
\hline & Document & No. of citations & Document & Total links strength \\
\hline 1. & Gordon, L.A. (2010) & 112 & Ali, M.A. (2018) & 44 \\
\hline 2. & Grimes, S. (2003) & 64 & Zhao, F. (2015) & 39 \\
\hline 3. & Kierkegaard, P. (2011) & 57 & Watanabe, C. (2018a) & 35 \\
\hline 4. & Polyakova A.G. (2019) & 50 & Watanabe, C. (2018b) & 33 \\
\hline 5. & Geiffrion, A,M. (2003b) & 50 & Geoffrion, A.M. (2003a) & 19 \\
\hline 6. & Akyuz, G.A. (2009) & 47 & Geoffrion, A.M. (2003b) & 19 \\
\hline 7. & De Cock, C. (2000) & 38 & Kuznetsova, I.G. (2018) & 16 \\
\hline 8. & Li, F. (2016) & 36 & Ivanova, V. (2019) & 14 \\
\hline 9. & Cronin, B. (2001) & 35 & Oumlir, R. (2018) & 13 \\
\hline 10. & Geoffrion, A.M. (2003a) & 32 & Burkaltseva, D.D. (2017a) & 11 \\
\hline 11. & Afonosova, M.A. (2019) & 26 & Burkaltseva, D.D. (2017b) & 11 \\
\hline 12. & Kostakis, V. (2016) & 25 & Olleros, X. (2008) & 9 \\
\hline 13. & Ivanova, V. (2019) & 24 & Kologlugil, S. (2015) & 7 \\
\hline 14. & Watanabe, C. (2018a) & 24 & Polyakova A.G. (2019) & 6 \\
\hline 15. & Veselovsky, M.Y. (2018) & 22 & Lee, S.M. (2011) & 6 \\
\hline 16. & Burkaltseva, D.D. (2017b) & 22 & Geoffrion, A.M. (2002) & 6 \\
\hline 17. & Zhao, F. (2015) & 22 & Glotko, A.V. (2020) & 5 \\
\hline 18. & Vlasov, A.I. (2019) & 21 & Curran, D. (2018) & 5 \\
\hline 19. & Spiekermann, S. (2017) & 21 & Mueller, S.C. (2017) & 5 \\
\hline 20. & Kim, B. (2002) & 21 & Teng, C.I. (2006) & 5 \\
\hline
\end{tabular}

Source: Author, March 2021

\subsection{Keyword analysis}

Co-occurrence refers to the case where two keywords appear together in the analyzed documents and it enables researchers to define the focus of the analyzed topic. In this way, a cluster is formed by the words that best describe it and the connections between them. The research was conducted on three levels. The author, index, and total keywords were used to single out terms that are in all cases associated with synonyms for the digital economy. For all three variants of keyword research, a minimum condition of five occurrences was set, with 21 author keywords excluded from 1,176 keywords. Of the 490 indexed keywords, only 10 meet the condition. Out of the 1,531 total keywords, 33 meet the condition. The keywords are shown in Table 4. 
Table 4 Keyword comparison

\begin{tabular}{|c|c|c|c|c|c|c|c|c|c|}
\hline & $\begin{array}{l}\text { Author } \\
\text { keywords }\end{array}$ & $\begin{array}{l}\text { No. of oc- } \\
\text { curences }\end{array}$ & $\begin{array}{c}\text { Total link } \\
\text { strength }\end{array}$ & $\begin{array}{c}\text { Index } \\
\text { keywords }\end{array}$ & $\begin{array}{l}\text { No. of oc- } \\
\text { curences }\end{array}$ & $\begin{array}{c}\text { Total link } \\
\text { strength }\end{array}$ & $\begin{array}{c}\text { Total } \\
\text { keywords }\end{array}$ & $\begin{array}{l}\text { No. of oc- } \\
\text { curences }\end{array}$ & $\begin{array}{c}\text { Total link } \\
\text { strength }\end{array}$ \\
\hline 1. & $\begin{array}{c}\text { Digital } \\
\text { Economy }\end{array}$ & 242 & 132 & $\begin{array}{l}\text { Digital Econ- } \\
\text { omy }\end{array}$ & 41 & 45 & $\begin{array}{c}\text { Digital } \\
\text { Economy }\end{array}$ & 271 & 243 \\
\hline 2. & $\begin{array}{l}\text { Digitaliza- } \\
\text { tion }\end{array}$ & 23 & 32 & $\begin{array}{l}\text { Electronic } \\
\text { Commerce }\end{array}$ & 9 & 17 & $\begin{array}{l}\text { Innova- } \\
\text { tion }\end{array}$ & 19 & 46 \\
\hline 3. & Innovation & 15 & 24 & Marketing & 7 & 15 & $\begin{array}{l}\text { Digitaliza- } \\
\quad \text { tion }\end{array}$ & 23 & 41 \\
\hline 4. & Internet & 10 & 16 & Economics & 7 & 14 & Internet & 14 & 36 \\
\hline 5. & Digitization & 7 & 15 & $\begin{array}{l}\text { Industrial } \\
\text { Economics }\end{array}$ & 6 & 13 & $\begin{array}{c}\text { Electronic } \\
\text { Com- } \\
\text { merce }\end{array}$ & 10 & 29 \\
\hline 6. & Big Data & 8 & 14 & Data Privacy & 8 & 10 & $\begin{array}{c}\text { Data } \\
\text { Privacy }\end{array}$ & 10 & 28 \\
\hline 7. & E-commerce & 8 & 14 & Competititon & 5 & 10 & $\begin{array}{l}\text { Digitiza- } \\
\text { tion }\end{array}$ & 9 & 26 \\
\hline 8. & $\begin{array}{l}\text { Economic } \\
\text { Growth }\end{array}$ & 8 & 14 & Innovation & 5 & 10 & Marketing & 7 & 24 \\
\hline 9. & Technology & 8 & 14 & $\begin{array}{c}\text { Economic } \\
\text { Analysis }\end{array}$ & 6 & 7 & $\begin{array}{c}\text { Economic } \\
\text { Growth }\end{array}$ & 9 & 23 \\
\hline 10. & $\begin{array}{c}\text { Artificial } \\
\text { Intelligence }\end{array}$ & 6 & 13 & $\begin{array}{c}\text { Sustainable } \\
\text { Development }\end{array}$ & 6 & 5 & Privacy & 8 & 23 \\
\hline 11. & $\begin{array}{l}\text { Information } \\
\text { Tecnologies }\end{array}$ & 6 & 13 & & & & $\begin{array}{l}\text { Industrial } \\
\text { economics }\end{array}$ & 6 & 23 \\
\hline
\end{tabular}

Source: Author, March 2021

Overlay visualization of total keywords shows that in recent years, depending on the focus of the authors, the words digitization, big data, innovation or digital technologies are used more frequently compared to e-commerce and e-business that were used in earlier documents. Figure 3 also shows great interest that prevailed 4-6 years ago in the field of data privacy and data protection. This shows that the focus of researchers is shifting to new digital technologies and research into the elements and development of the digital economy.

\section{Figure 3. Total keyword overlay visualization}

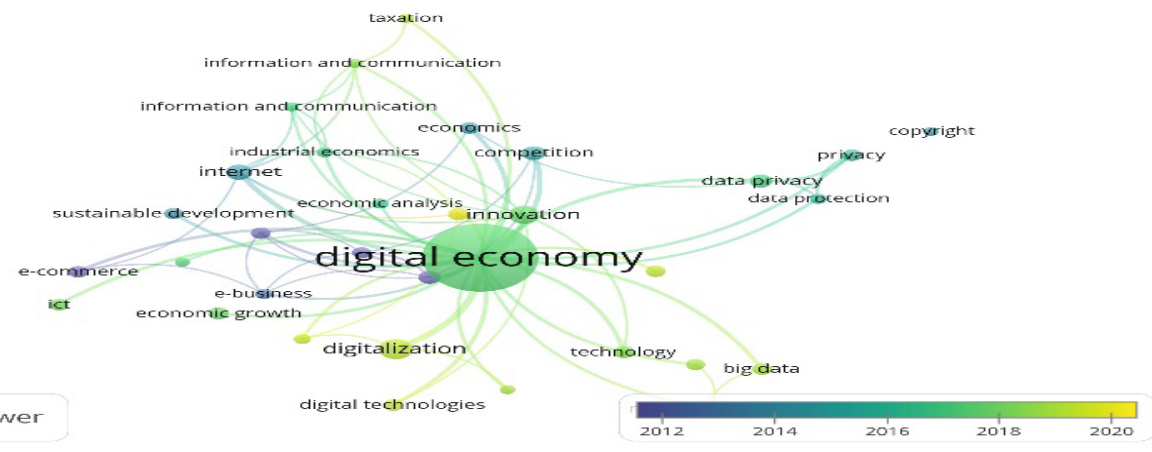

Source: VOSviewer analysis, 2021 
It can be noted that most keywords could not be defined as a macroeconomic term, but the digital economy is associated with digital terms such as digitalization, innovation, the Internet and new technologies, which refutes the thesis that the digital economy is associated with macroeconomic terms. At the same time, index keywords focus the area on marketing, economics, data protection, etc. Although this would be expected due to the pronounced impact of the digital economy on society, it can be concluded that it is still unclear what the digital economy encompasses, how it is measured and what its impact is on the overall economy. If we also look at the titles of articles obtained by keyword research in the Scopus database, we can see that most articles deal with a specific field of industry instead of the notion of the digital economy and its impact on the economy as a whole. It is also interesting to note that the keywords have no synonyms for the digital economy: Industry 4.0, knowledge economy, etc.

\section{Results and discussion}

The topic of the digital economy has been present in research for more than 20 years. However, the interest of the research community in the field under study has grown significantly in recent years. Despite the fact that a large number of authors $(12,828$ cited) deal with this field, bibliographic analysis shows that a very small number of authors (59) were cited more than 20 times $(22.5 \%$ of all authors in the analysis account for $47.14 \%$ of all citations). However, although Gordon, Loeb, and Sohail are the most cited authors, co-citation analysis shows that Watanabe and Neittaanmaki are the authors who are embedded in the very foundations of the topic.

Thereby, MIS Quarterly is the most cited journal in which documents have been published that form the basis for the development of the topic of the digital economy. Abstract analysis shows that a very small number of documents that use the term digital economy in keywords and abstracts actually refer to this field, i.e. define the digital economy and its scope. Of the five most cited documents, only one refers to the digital economy in the title.

According to Škuflić \& Dizdarević (2003), there is no single definition of the digital economy. The terms new economy (Šonje, 2001; Mann \& Rosen, 2001; Atkinson \& Gottlieb, 2001; Tapscott,
1996; Perkov, 2019), information economy (Šonje, 2001; Ajeti, 2003) knowledge society (Atkinson, 2000; Drašković, 2010), and information society (Krajina \& Perišin, 2009) are also used. Škuflić \& Dizdarević (2003) reduce different definitions of the digital economy under the common denominator of economic growth with "intensive involvement of information and communication technology (ICT sector) in all areas of the economy and society which causes changes on the supply and demand side".

It is important to note that the definition of the digital economy changes with time it is given in and the prevailing technology of that time, from the Internet to advanced robotics and artificial intelligence. We are witnessing the rapid development of technology, so today's definitions will become obsolete in the future due to the emergence of some new technologies that will mark the time in which the digital economy will be defined. Earlier definitions (Tapscott, 1995) focused mainly on the Internet explaining its importance during the 1990s. With the development of digital technologies, the digital economy is later explained by means of computers and mobile communications (Šonje, 2001), IOT, social networks, sensors (Digital Croatia, 2014), big data, cloud computing, robotics, artificial intelligence - depending on the time the definition is given in.

Definitions of the digital economy can be divided into three groups. The first group (Atkinson, 2000; Ajeti, 2003; Drašković, 2010) describes knowledge as one of the key factors, i.e. in the current phase of digital technology development, it puts people and their knowledge in the foreground. The digital economy has emerged based on knowledge and due to the development of knowledge, it will continue to develop. According to Atkinson (2000), the digital economy is "an economy based on knowledge and ideas about where the key to improving living standards and creating new jobs is, to the extent that innovative ideas and technological changes are incorporated into products, services and production processes".

Ajeti (2003) concludes that "education is becoming crucial for the functioning of modern knowledge-based information societies and that the knowledge economy uses knowledge as the best quality goods/assets, as a means of production and guarantees of competitive advantages in the market". 
Drašković (2010) also puts people at the center of the definition and believes that the knowledge economy "is formed and expanded on the basis of knowledge as a factor that is impossible to replace with other factors. This knowledge is transformed into goods and income in most economic activities, not only in those related to advanced technologies" (Drašković, 2010).

The second and largest group (Lane, 1999; Šonje, 2001; Mann \& Rosen, 2001; Digital Croatia, 2014; Knickrehm et al., 2016) includes definitions that are based on technology as a key driver of development with the aim of achieving growth and profit. Such "technological" definitions do not speak of a human as the initiator and user of the values of the digital economy.

Šonje (2001) considers that "new economy (e-economy or information economy) terms are terms that describe new products, services and markets relat-

\section{Table 5 Digital economy definitions}

\begin{tabular}{|c|c|c|}
\hline Source & Definition & Focus \\
\hline Tapscott (1995) & Economy based on digital computer technologies & Technology \\
\hline Lane (1999) & $\begin{array}{l}\text { Convergence of computer and communication technology to the Inter- } \\
\text { net and the resulting flow of information and technology that stimu- } \\
\text { lates all e-commerce and huge organizational changes }\end{array}$ & Technology \\
\hline Atkinson (2000) & $\begin{array}{l}\text { A knowledge-based economy and ideas about where the key to im- } \\
\text { proving living standards and job creation to the extent that innovative } \\
\text { ideas and technological changes are incorporated into products, ser- } \\
\text { vices and production processes }\end{array}$ & $\begin{array}{c}\text { Knowledge and } \\
\text { people }\end{array}$ \\
\hline Šonje (2001) & $\begin{array}{l}\text { New economy (e-economy or information economy) terms that de- } \\
\text { scribe new products, services and markets related to the use of com- } \\
\text { puters and mobile communications, and especially the Internet }\end{array}$ & Technology \\
\hline $\begin{array}{l}\text { Mann and Rosen } \\
(2001)\end{array}$ & $\begin{array}{l}\text { An economic model based on interrelated policies aimed at achieving } \\
\text { sustainable long-term growth, with connected information technolo- } \\
\text { gies drastically increasing the amount and value of information avail- } \\
\text { able to individuals, companies, markets and governments, enabling } \\
\text { them to make more efficient choices and achieve superior results }\end{array}$ & Technology \\
\hline $\begin{array}{c}\text { Škuflić and } \\
\text { Dizarević (2003) }\end{array}$ & $\begin{array}{l}\text { Economic growth with intensive involvement of information and com- } \\
\text { munication technology (ICT sector) in all areas of the economy and } \\
\text { society, which causes changes on the supply and demand side }\end{array}$ & Technology \\
\hline Ajeti (2003) & $\begin{array}{l}\text { Education is becoming crucial for the functioning of modern informa- } \\
\text { tion societies based on knowledge. Knowledge economy uses knowl- } \\
\text { edge as the best quality goods / assets, as a means of production and a } \\
\text { guarantee of competitive advantages in the market }\end{array}$ & $\begin{array}{c}\text { Knowledge and } \\
\text { people }\end{array}$ \\
\hline $\begin{array}{c}\text { Digital Croatia } \\
(2014)\end{array}$ & $\begin{array}{l}\text { A newer form of economy based on digital technologies, and as such } \\
\text { represents one of the most attractive trends and opportunities for } \\
\text { growth }\end{array}$ & Technology \\
\hline
\end{tabular}

ed to the use of computers and mobile communications and especially the Internet".

Mann \& Rosen (2001) define the new economy as "an economic model based on interrelated policies aimed at achieving sustainable long-term growth, with related information technologies drastically increasing the amount and value of information available to individuals, businesses, markets and governments, enabling them to make a more efficient choice and achieve superior results". Knickrehm et al. (2016) consider that "the digital economy is the share of the total economic product that arises from a certain number of digital inputs. Digital inputs include digital skills, digital equipment (hardware, software, and communication equipment), digital goods and services used in the production system. Such broad measures reflect the foundations of the digital economy." Table 5 shows the development and inconsistency in relation to the focus of the definition of the digital economy over time. 


\begin{tabular}{|c|c|c|}
\hline Source & Definition & Focus \\
\hline $\begin{array}{l}\text { European Parlia- } \\
\text { ment (2015) }\end{array}$ & $\begin{array}{l}\text { The digital economy is a complex structure of several levels intercon- } \\
\text { nected by an almost infinite and ever-growing number of nodes. Inter- } \\
\text { connected platforms provide access to end users through a number of } \\
\text { routes, which makes it difficult to exclude certain players, i.e. competi- } \\
\text { tors }\end{array}$ & Connectivity \\
\hline Hržica (2016) & $\begin{array}{l}\text { The digital economy is based on the added value generated by new } \\
\text { technologies }\end{array}$ & Technology \\
\hline Rouse (2016) & $\begin{array}{l}\text { World Network of Economic Activities Enabled by Information and } \\
\text { Communication Technologies (ICT) }\end{array}$ & Connectivity \\
\hline $\begin{array}{l}\text { Knichrem et al. } \\
\qquad(2016)\end{array}$ & $\begin{array}{l}\text { The digital economy is the share of the total economic product that } \\
\text { results from a certain number of digital inputs. Digital inputs include } \\
\text { digital skills, digital equipment (hardware, software and communica- } \\
\text { tion equipment) and digital goods and services used in the production } \\
\text { system. Such broad measures reflect the foundations of the digital } \\
\text { economy }\end{array}$ & Technology \\
\hline $\begin{array}{l}\text { Dahlman et al. } \\
\qquad(2016)\end{array}$ & $\begin{array}{c}\text { The digital economy is a combination of several general technologies } \\
\text { and a range of economic and social activities carried out by people } \\
\text { over the Internet and related technologies }\end{array}$ & Technology \\
\hline Spremić (2017) & $\begin{array}{l}\text { The term digital economy serves as an umbrella term to denote new } \\
\text { business models, products and services based on digital technologies } \\
\text { as the basic business infrastructure }\end{array}$ & Technology \\
\hline
\end{tabular}

Source: Author, March 2021

The main difference between the definitions of the first and the second group of authors is that the first group assumes knowledge (people) as a basis for the development of the digital economy that should improve the living standards of the population. Educated and creative, people are the ones who make a difference. In contrast, the second group explains the digital economy by focusing on technology as the main feature and business performance as the target output.

The third group of definitions consists of definitions (European Parliament, 2015; Rouse, 2016) that put connectivity at the center or as a basic characteristic of the digital economy. According to the definition of the European Parliament (2015), "the digital economy is a complex structure of several levels interconnected by an almost infinite and ever-increasing number of nodes.

Interconnected platforms allow access to end-users through a number of routes, which makes it difficult to exclude certain players, i.e. competitors". Rouse (2016) defines the digital economy as a global network of economic activities enabled by information and communication technologies (ICT). According to these definitions, it can be concluded that the backbone of the digital economy is hyperconnectivity, which implies the growth of interconnectedness of people, organizations and devices through the Internet, mobile technologies and the Internet of Things.

In order to determine the definition of the digital economy, it is also important to discuss the social character of the digital economy, which is still largely described by the development of digital technologies and very little by the role of people in such an economy. How is the digital economy defined, what are its key elements and how does it differ from the "old economy"? Most of these authors use the terms knowledge, technological change, education, longterm growth, and connectivity. However, the same terms were used during the industrial revolutions in both earlier definitions of the economy and for the non-digital economy. Knowledge, education and technological change have been key characteristics at every stage of economic development. The digital economy is characterized by something else. Industrialization has brought machines to humanity that have been used to advance society but were controlled by people. The digital economy brings, among other things, big data, artificial intelligence, advanced robotics, and the role of man is still un- 
defined at this stage of development of such a society. Today, people still live in a divided economy between the "outdated" and the "digital" economy and use the benefits of both. However, could one really imagine what the world would look like at the time when the concept of the "old" economy would be completely abandoned?

Could one imagine a fully digitalized world governed by artificial intelligence in which, due to advanced robotics, the role of man would become secondary? Would we become unnecessary or provide a way to manage systems?

These are the questions that were not asked during the industrial revolutions because we had mancontrolled machines. Although it seems that we have come a long way in the development of digital technologies, we should be aware that we are at the very beginning. Therefore, it is especially important to emphasize once again that the previously analyzed definitions of the digital economy are based on what is known today and not on what will be known tomorrow.

\section{Conclusion}

The digital economy has become an unavoidable topic in recent literature, which has been reflected in the significant growth in the number of documents that analyze the impact of the digital economy on a wide range of thematic clusters. This document significantly contributes to the understanding of the term digital economy, systematizing and analyzing various definitions of the digital economy, including the time impact of technology development on the definitions.

Bibliographic analysis shows a significant influence of a small number of journals, documents and authors on the field under study. The importance of bibliographic analysis is especially reflected in determining the foundations of the field under study. Although some authors are top-cited authors, cocitation and bibliographic coupling analyses show that some other authors are embedded in the very foundations of the field or, that they are much more networked in the discussion. A similar conclusion can be drawn for journals and documents.

However, although certain journals are on the list of the most cited, analysis of the number of documents published in journals largely shows both the quality of the document itself and the rigor of the selection of documents by the journal. In specific cases, by using a comparison of the number of documents in the journal and the number of citations of the journal, it can be concluded that the quantity of papers does not necessarily contribute to the quality of the journal itself.

Bibliographic analysis did not confirm hypothesis 1. The digital economy in keywords is not related to macroeconomic concepts but to certain professional concepts of information technology. Despite a general understanding of the digital economy as a macroeconomic concept, it is not explained in the literature on such principles.

It can be concluded that, despite the fact that it is often referred to in recent documents as the economy of the future, the digital economy is still limited to a certain set of activities using information technology and as such is still not determined by the composition, scope and contribution to global trends. Literature analysis also identified key features of the digital economy such as knowledge, globalization, digital business models, the speed of change, supporting infrastructure, integration of independently developed technologies and the use of digital platforms, inequality of development by country, the need for education and the duality of economy - simultaneous existence of "old" and new "digital" economies.

Based on the discussion, certain questions arise that future research should address:

1. What does the digital economy encompass?

2. How is the size of the digital economy measured?

3. How is the impact of the digital economy on the economy measured?

4. What is the supreme body where the answers to the above questions will be agreed upon?

It has been proven that different authors understand the concept of the digital economy differently. This confirms hypothesis 2 that there is still no consensus on the question as to what the digital economy is and what its scope and area are. Therefore, it is extremely important that future research answers these questions as soon as possible in order to uniquely define, develop and measure the digital economy as a clearly defined field that is justifiably considered the basis of future economic trends. Al- 
though a large number of definitions of the digital economy are present in the literature, very few documents attempt to define the boundaries of the digital economy as well as the mode of measurement. Will we consider and measure the digital economy only as the benefit that digital technologies create to the traditional economy? Will we consider the digital economy as products and services that are created exclusively through the application of digital technologies, or will we attribute the complete value of these products and services to the digital economy, regardless of the fact that only one part depends on digital technologies? The lack of measurement of the digital economy could be explained by the fact that the digital economy is an integral part of the global economy. It is still developing through the rapid development of digital technologies that become either part of "old technology" or independent technology that creates products and services. With the further development of digital technology and further taking over of the functions of "old" technology, the digital economy will grow to the point where it will be possible to establish a clear boundary between products and services created by the application of old or new technology.

At this point, arguments can be found that explain the attitudes of both "parties" - why a product and/ or service could be considered and measured as part of the digital or the traditional economy. 


\section{REFERENCES}

1. Atkinson, R. D. (2000). Making the New Economy Grow. Progressive Policy Institute.

2. Atkinson, R. D. \& Gottlieb, P. D. (2001). The Metropolitan New Economy Index. Progressive Policy Institute.

3. Ajeti, M. (2003). Uloga ekonomije znanja i poduzetništva u razvojnoj strategiji regionalne ekonomske politike. University of Ljubljana, Faculty of Economics.

4. Ajibade, P. \& Mutula, S. S. M. (2018). Bibliometric Analysis of Citation Trends and Publications on E-government in Southern African Countries: A Human-computer Interactions and IT alignment Debate. Library Philosophy and Practice, 2234.

5. Barmuta, K. A., Akhmnetshin, E. M., Andryushchenko, I. Y., Tagibova, A. A., Meshkova, G. V. \& Zekiy, A. O. (2020). Problems of business processes transformation in the context of building digital economy. Entrepreneurship and Sustainability Issues, Vsl Entrepreneurship and Sustainability Center, 8(1), 945-959. https://doi.org/10.9770/jesi.2020.8.1(63)

6. Bukht, R. \& Heeks, R. (2017). Defining, Conceptualising and Measuring the Digital Economy (Working Paper No. 68). Manchester: Center for Development Informatics, Global Development Institute, SEED. https://doi.org/10.2139/ssrn.3431732

7. Caputo, A., Pizzi, S., Pellegrini, M. M. \& Dabić, M. (2021). Digitalization and business model: Where are we going? A science map of the field. Journal of Business Research, 123, 489-501.

https://doi.org/10.1016/j.jbusres.2020.09.053

8. Callon, M., Courtial, J. P., Turner, W. A. \& Bauin, S. (1983). From translation to problematic networks: An introduction to co-word analysis. Social Science Information, 22(2), 191-235.

https://doi.org/10.1177/053901883022002003

9. Chen, Y. (2020). Improving market performance in the digital economy. China Economic Review, 62(August), 101482. https://doi.org/10.1016/j.chieco.2020.101482

10. Dewan, S. \& Kraemer, K. L. (2000). Information technology and productivity: Preliminary evidence from country-level data. Management Science, 46, 29-51. https://doi.org/10.1287/mnsc.46.4.548.12057

11. Digital Croatia (2014). Što je digitalna ekonomija? Ministry of Economy, Entrepreneurship and Crafts. http://www.digitalnahrvatska.org/sto-je-digitalna-ekonomija/

12. Drašković, M. (2010). Znanje kao neograničeni resurs i objekt upravljanja. Montenegrin Journal of Economics, 6(11), 83-90.

13. Ergunova, O., Skuratov, A., Pozdeeva, O. \& Kindaev, Y. (2019). Opportunities and emerging trends for digitalization of Rusian economy. IOP Conference Series: Materials Science and Engineering, 483(1), 012115. https://doi.org/10.1088/1757-899X/483/1/012115

14. European Parliament (2015). Challenges for Competition Policy in a Digitalised Economy. Publication Office of the European Union.

15. Ferreira, F. A. F. (2018). Mapping the field of arts-based management: Bibliographic coupling and co-citation analysis. Journal of Business Research, 85, 348-357. https://doi.org/10.1016/j. jbusres.2017.03.026

16. Friedrich, R., Le Merle, M., Gröne, F. \& Koster, A. (2011). Measuring industry digitization: Leaders and laggards in the digital economy. PWC. https://www.strategyand.pwc.com/gx/en/insights/2002-2013/ measuring-industry-digitization/strategyand-measuring-industry-digitization-leaders-laggardsdigital-economy.pdf

17. Huggins, R. (2008). The evolution of knowledge clusters: Progress and policy. Economics Development Quarterly, 22(4), 277-289. https://doi.org/10.1177/0891242408323196

18. Krajina, Z. \& Perišin, T. (2009). Digitalne vijesti: mediji, tehnologija i društvo. Društvena istraživanja, 18(6), 935-956. 
19. Knickrehm, M., Berthon, B. \& Daugherty, P. (2016). Digital disruption: The growth multiplier. Accenture. https://www.accenture.com/_acnmedia/PDF-14/Accenture-Strategy-Digital-DisruptionGrowth-Multiplier-Brazil.pdf

20. Kessler, M. M. (1963). Bibliographic coupling between scientific papers. Jasist, 14(1), 10-25. https://doi.org/10.1002/asi.5090140103

21. Kupenova, Z., Baimukhanova, S., Nurgalieva, G., Zhunisova, G. \& Nurmukhan, A. (2020). Digital economy and its role in accounting. E3S Web of Conferences. https://doi.org/10.1051/ e3sconf/202015904032

22. Lane, N. (1999). Advancing the Digital Economy into the 21st Century. Information Systems Frontiers, 1(3), 317-320. https://doi.org/10.1023/A:1010010630396

23. Mann, C. L. \& Rosen, D. H. (2001). The New Economy and APEC. Peterson Institute for International Economics.

24. Miethlich, B., Belotserkovich, D., Abasova, S., Zatsarinnaya, E. \& Veselitsky, O. (2020). Digital economy and its influence on competitiveness of countries and regions. Espacios, 41(12), 20-31.

25. Nguyen, T. V. \& Pham, L. T. (2011). Scientific output and its relationship to knowledge economy: an analysis of ASEAN countries. Scientometrics, 89(1), 101-117.

https://doi.org/10.1007/s11192-011-0446-2

26. Negroponte, N. (1995). Being Digital. Alfred A. Knopf, Inc.

27. Nesterenko, N. Y., Pakhomova, N. V. \& Richter, K. K. (2020). Sustainable development of organic agriculture: Strategies of Russia and its regions in context of the application of digital economy technologies. St. Petersburg University Journal of Economic Studies, 36(2), 217-242.

https://doi.org/10.21638/spbu05.2020.203

28. Nitescu, A. (2016). Trends and Dimensions of Digital Economy. Annals of the "Constantin Brancusi" University of Targa Jiu, Economy Series, 2016(4), 103-107.

29. Novikov, S. (2020). Data Science and Big Data Technologies Role in the Digital Economy. TEM Journal, 9(2), 759-762. https://doi.org/10.18421/TEM92-44

30. Ojanpera, S., Graham, M. \& Zook, M. (2019). The Digital Knowledge Economy Index, Mapping Content Production. The Journal of Development Studies, 55(12), 2626-2643.

https://doi.org/10.1080/00220388.2018.1554208

31. Perkov, D. (2019). Upravljanje promjenama u poslovnoj organizaciji digitalnog doba. Narodne novine.

32. Pohjola, M. (2002). The new economy: Facts, impacts and politics. The Journal of Information Economics and Policy, 14(2), 133-144. https://doi.org/10.1016/S0167-6245(01)00063-4

33. Reznik, O., Danylevska, Y., Steblianko, A., Chekmarova, I. \& Karelin, V. (2020). Current Status of Prospects of Anti-Money Laundering in Digital Economy. REICE: Revista Electronica de Investigacion en Ciencias Economicas, 8(15), 314-327. https://doi.org/10.5377/reice.v8i15.9962

34. Rouse, M. (2016). Digital Economy. Techtarget.

35. Rrustemi, J. \& Tuchschmid, N. S. (2020). Fundraising Campaigns in a Digital Economy: Lesson from a Swiss Diamond Venture's Initial Coin Offering (ICO). Technology Innovation Management Review, 10(6), 53-63. https://doi.org/10.22215/timreview/1368

36. Shibata, S. (2020). Gig Works and the Discourse of Autonomy: Fictitious Freedom in Japan's Digital Economy. New Political Economy, 25(4), 535-551. https://doi.org/10.1080/13563467.2019.1613351

37. Solis, B. \& Szymanski, J. (2016). The 2016 State of Digital Transformation. Altimeter Group.

38. Spremić, M. (2017). Governing Digital Technology - How Mature IT Governance can help in Digital Transformation?. International Journal of Economics and Management Systems, 2, 214-223.

39. Surwase, G., Sagar, A., Kademani, B. S. \& Bhanamurthy, K. (2011). Co-citation Analysis: An Overview. In Kademani B. S. et al. (Eds.), BOSLA National Conference Proceedings. (pp. 179-185). Mumbai: Bombay Science Librarians' Association. 
40. Šonje, V. (2001). Izazov "Nove ekonomije": Od računala i interneta do elektronskog novca. Privredna kretanja i ekonomska politika, 11(86), 64-80.

41. Škuflić, L. \& Vlahinić-Dizdarević, N. (2003). Koncept nove ekonomije i značaj informacijskokomunikacijske tehnologije u Republici Hrvatskoj. Ekonomski pregled, 54(5-6), 460-479.

42. Tapscott, D. (1995). The Digital Economy: Promise and Peril in the Age of Networked Intelligence. McGraw-Hill.

43. Tapscott, D. (1996). The Digital Economy: Rethinking the Promise and Peril in the Age of Networked Intelligence. McGraw-Hill.

44. Ugli, R. D. J. \& Khurramov, A. M. U. (2020). The Concept of Digital Economy in Modern Life and Its Implication to Life. JournalNX, 6(5), 118-121.

45. Van Eck, N. J. \& Waltman, L. (2010). Software survey: VOSviewer, a computer program for bibliometric mapping. Scientometrics, 84(2), 523-538. https://doi.org/10.1007/s11192-009-0146-3

46. Yousefi, A. (2011). The impact of information and communication technology on economics growth: Evidence from developed and developing countries. Economics of Innovation and New Technology, 20(6), 581-596. https://doi.org/10.1080/10438599.2010.544470 